\title{
Study on the Three-stage System of Continuous Music Education in the Old Russian Singing Art
}

\author{
Oksana Sheludyakova \\ Urals Mussorgsky State Conservatoire \\ Yekaterinburg, Russia
}

\author{
Elena Polotskaya \\ Urals Mussorgsky State Conservatoire \\ Yekaterinburg, Russia
}

\begin{abstract}
The article is devoted to the description of the Old Russian period of the history of professional music education. It highlights the philosophical foundations of church and chanting pedagogy, examines specifics, organizational forms, principles and methods of the system of singers' and chanters' three-level education.
\end{abstract}

Keywords-three-stage system of education; continuous music education; Old Russian singing art; old Russian chants

\section{INTRODUCTION}

Choir education in Ancient Rus is a full-fledged pedagogical process. First, it is required by society as a social service of professional church singers; second, society provides the appropriate organizational forms and hence the conditions for effective education. Third, there are two levels of choir education: general one and professional one; finally, there are three stages of professional church and singing education.

\section{THE FIRST ST AGE OF PROFESSIONAL CHURCH AND SINGING EDUCATION}

The specifics of the general choir education in Ancient Rus reveals a paradox: general education is also the first stage of professional education. Moreover, Old Russian church choir pedagogy emerges as the pedagogy of vocational training. What does the history tell us in this regard?

Choir pedagogy as the ancient Russian singing culture in general begins with the adoption of Byzantine cultural base. There is a long way to transform it and form the country's own national musical pedagogy.

This process is invariably controlled by the state. Thus, the first state decree on the problems of professional singing training dates back to 1274, when the Council of Vladimir decides to establish a system of compulsory special education of the future choir singers. It is necessary to note a "declaration" of this decree as it is very important and significant from the point of view of spiritual education: a singer should have been not only well educated but also devoted to his profession, that is, ranked as a clergy man with the right to serve the Church not only at the altar [1] [2].

The second period of the history of church and singing pedagogy is marked by the Stoglav Council of 1551, which results in resolutions on the control of the state of books, including those for singing for which worship is performed ("on correction of the book"1), and on the establishment of so-called "book schools" which goal is to teach children literacy, book writing and church singing (see: [4]): "... that the priests and deacons and all Orthodox Christians in the city where their children were taught to read, write, and sing in church, and those chosen priests and deacons would teach their disciples the fear of God and reading, writing, signing and honor with all spiritual punishment ... "(Makariyevsky Stoglavnik. Cit. by: [5]).

In fact, this is the first decree of the Old Russian state on universal 2 orthodox-oriented primary education. Let us emphasize that the obligatory minimum includes also liturgical singing. This is followed by two major provisions of pedagogy of the period under study, namely:

- The first stage of professional singing education is carried out within the frame work of universal primary theological education being an integral part of it;

- The Old Russian educational system as a whole is characterized by syncretis $m$.

In this case, pedagogy is again a product of its time and corresponds to the Old Russian cultural paradigm, of which syncretism is an ontological property (see: [6]). General and professional education are inseparable, and a certain level of general Christian upbringing and education becomes the guarantee of some primary professionalism in the field of church singing, which confirms the predominance of the spiritual and educational mission of pedagogy over purely educational one.

\section{THE SECOND ST AGE OF PROFESSIONAL CHURCH AND SINGING EDUCATION}

The choice of church singing as a profession can take place already at the first stage of general education, since the

\footnotetext{
"And holy books of evangelist ary and apostles and psalters and other books that are found uncorrected and described, and you would have all those holy books from good translations corrected together by all clergymen as the sacred rules forbid and do not order to have the uncorrected books in church, let alone sing by them" (Makaryevsky Stoglavnik. Cit. by: [3]).

Naturally, one should take into account social constraint s of the medieval feudal society.
} 
professional intentions of the students are not determined by the school and singing specialization which simply does not exist, unlike, for example, dynastic factor, blessing of a confessor, etc. Professionalism as such, brings the possibility, among other things, to actually earn a living emerges precisely when a person joins the choir. Thus, the choir singing is the basis of the professional church and singing education of the second stage.

By itself, the choir singing in Old Russia has certain gradations in the level of professionalis $\mathrm{m}$. Thus, not in every church one can hear choral singing, "since most Russian churches, especially parish churches, are poor and their clergy of a parish are just a few people" [7]. In such churches, the choir is not supposed to be a clergymen one, and, as a rule, the singers' functions combined with the functions of the reciters are performed by one or two vicar choirs [7]. Of course, the level of professionalism in such cases does not exceed the initial stage of singing education.

Professional choir singing in a choir place is a privilege of the monasteries, as well as the courts of the higher secular aristocracy and clergy. These are monastic and court choirs that laid the tradition of Russian choral singing, the distinctive features of which are still spiritual and highly skillful.

Throughout the history of the Old Russian Orthodox culture, monasteries have been the centers of church and choir education. It is known that "the very origin of Russian liturgical singing is closely connected with the formation of Russian monasticism ... The liturgical singing is an integral part of the teaching program in monasteries. Confirmation of this is found in the annals, as well as the writings of prominent Orthodox thinkers of Ancient Rus. Thus, Nil Sorsky (circa 1433-1508) summarizing the experience of monastic education considers the optimal rhythm of "spiritual work" in monasteries a three-hour cycle: an hour to pray, an hour to read and an hour to sing ... The Kiev Monastery of the Caves Patericon, a collection of stories about the exploits of the Caves monks of the 11th-12th centuries, says that the founder of this monastery, Theodosius of Caves, "established the way to sing the monastic singing, the way of bowing and reading" " [1].

At different times, the prominent centers of church and singing culture are Kiev Monastery of the Caves, Cyril of White Lake, Solovetsky, Chudov, Trinity-Sergius monasteries. In the 15th, 16th and 17th centuries, women's monasteries became such centers as well: Novodevichya and Voskresenskaya in Moscow, Pokrovskaya in Suzdal. It is noteworthy that singing schools are established within the monastery walls, and, in these schools, the teachers are prominent masters of the time. Among them are Vasily (Varlam) Rogov (Kirillo-Belozersky Monastery), Ivan (Isaiah) Lukoshko (Christmas Monastery in Vladimir), and Login (Loggin) Korova (a member of the Moscow monastic school).

The court choirs of the ancient Russian state include bishop choirs equal in number to the number of dioceses, as well as the choir of the state vicar chorals and the choir of the patriarchal singers. The latter two are the main choirs of the Russian state, since they serve the tsar and the patriarch. By the nature of the activity and the level of professionalism, both choirs are identical. Their main difference is only in the person they serve, i.e. the tsar or the patriarch. The lower eparchial choirs resemble them.

By the time of their heyday - the 16th century - both major choirs have had a long story of their development. The choir of the tsar's vicar chorals is founded by the grand prince church choir in the period of the reign of Ivan Kalita (the first half of the 14th century). There is an assumption that the patriarchal choir is even more ancient - originally it is a metropolitan choir appearing "apparently ... at the time of the establishment of the Metropolia in Russia (988). Since the introduction of the patriarchate in 1589, the choir has been called the patriarchal choir" [1]. Due to lack of proper historical confirmation, we will not talk about the nature of professional church and singing education at the time of its origins. Another important thing is that professional education originally has a very concrete form - the choir which is both an executive and an educational organization.

The choir's repertoire is distinguished by genre and style diversity. In addition to the chants of the echoes chant, the tsar's and the patriarch's singers of the clergy sing the vaults of the plain, travel, big echoes and other chants 3 , and this fact invariably confirms their high professionalism.

The main service and singing duties of the deacons include participation in divine services, non-service ceremonies, solemn and mourning ceremonies, escorts of the tsar and the patriarch and so on.

Among the non-singing functions of the deacons, the most important is "the training of young singers. It is entrusted, as a rule, to the most experienced deacons knowing all the subtleties of singing and having pedagogical skills..." [1]. It is noteworthy that the stanitsas (choral groups within the choir) are often formed according to the hierarchical principle of "teacher-pupil": "The leading stanitsas include teachers, professionals of high class, and in the so-called "other" or "small" stanitsas are students of different degrees of preparation, which does not prevent them from being also specialists, but only of lower qualification. "If necessary, the singers of the central choirs teach local singers" [1]. Thus, the professional education is given to the choristers in a practical way.

\section{THE THIRD ST AGE OF PROFESSIONAL CHURCH AND SINGING EDUCATION}

The third stage of professional choir education is associated with the education of the composing chanter of Ancient Rus. This stage is similar to the modern highest compositional education, and the only difference is that, apart from compositional mastery, a chanter continues to improve the Christian knowledge of the world and selfknowledge. The figure of the chanter is es pecially significant in the singing: it enters, in the words of P. Florensky, into the "special world of witnesses," a small nu mber of initiates who

\footnotetext{
Even the internal patriarchal choir of the patriarchal chant.
} 
by divine grace are permitted to create new songs, to invade the singing canon, to transform it and, thus, contribute to the evolution of the singing art. The chanter should feel the "sight of God", hear heavenly hymns4 and pass them on to people. It is at the third stage of the church singing education when a balance is achieved between spiritual, pedagogical and professional educational processes, since a chanter has to combine high spirituality and high professionalism.

Unlike the first two stages of choir education, the training of the chanter does not have a legislatively fixed organizational form. The chanters are grown out of professional singers, are brought up in choirs, in monasteries and in court choirs. One cannot speak of any specific form of training for a chanter since practice, which consisted in the individual transfer of knowledge by the chanting teacher to his most talented student, prevails. The student's talent becomes an indis pensable condition for the development of a chorister into a chanter.

It can be concluded that the mastery of the ancient Russian singing art includes, ideally, three stages similar to the triad "syncresis - analysis - synthesis." At the first stage, singers learn (most often from childhood) the general structure of the divine service and try to imbue with its spirit imperceptibly memorizing some hymns, vowels, etc.

The second stage consistently analyses and assimilates the individual aspects of singing art from certain hooked notation chants to phytah chants and varieties of monastic traditions.

At the final stage of training, heterogeneous information forms a holistic picture of the history and theory of church singing synthesized into a systemic representation of the worship of the Orthodox tradition and its singing component. The singers ascend to such a synthesis to become headmasters and didaskalos.

Let us now turn to the methodological positions of church and singing education in Ancient Rus. Initially, the Ladder is mastered, and along with it from the 17th century the system of postils has emerged. All designations and their decoding are to be memorized by heart. Further, the main hooked notation chants are learned: their inscriptions and names, way of intoning, correlation with other chants, variants of chanting, and, later, the interpretation of their spiritual meaning. In M. Brazhnikov's opinion, the "Alphabets" largely, if not completely, are "visual aids," and the use of them is to be accompanied by an oral explanation of a singing teacher" [9].

In general, the learning process combines two directions of knowledge:

- From the general moral requirements to their consistent mastering by the example of specific liturgical texts and the meanings of the notation chants;

\footnotetext{
"Church hymns are a copy of the heavenly "archetypes" so they must imitate heavenly patterns." (Pseudo-Dionysius Areopagite. "On the
} heavenly hierarchy." Cit. by: [8]).
- From concrete practice, from particulars to general theoretical principles, from individual tunes to a holistic picture of the eight church modes of the pivotal chanting and so on.

It is the combination of inductive and deductive methods that becomes one of the reasons for the viability of the singing tradition in Ancient Rus. The second stage of the training of singers is based on the successive mastering of singing books. For this, a mentor is necessary, and, more often than not, a headman didaskalos or a domestic who supervise the process of assimilation of church tunes, clarify incomprehensible words and expressions.

Books perform various functions in the pedagogical process. On the one hand, each of them presents a holistic view of a certain phenomenon: the voice column (the Octoechos), the daily circle (the Horologion), the annual circle (Menaia), liturgical genres (the Heirmologion, Troparion, Sticheron) and so on. On the other hand, the study of books seldom occurs consistently.

Some parts of the books are not noticed by the singers, so many chants sound once a year, but a whole series of prayers are performed at the divine service daily.

The initial fund of the liturgical tunes and their components (lines, melodies) is assimilated with the unchanging hymns, but at the same time, there is an awareness of multi-tune and fullness as one of the foundations of ancient Russian singing art. After all, the main prayers are performed at the divine service with varying degrees of chanting, different voices and sometimes various types of chant. In the future, such chants and their separate lines serve as a reminder, facilitating the mastering of new material.

The process of teaching singing by the Alphabets is very similar in structure to the literacy teaching process. Perhaps this is connected with the very name of the textbooks, the common one for the book and musical reading - the Alphabets. Initially, the inscription of letters and names and correct pronunciation of the notation chants are studied. Then, syllables, a combination of notation chants with different postils, are learnt. The next stage is the addition of syllables to words - the study of multi-stage notation chants; then, students proceed to combining words into phrases melodies and divided phyta chants.

At last, fluent reading means the ability to embrace a large phrase, a sentence as notation chants studies include the lines, the most complex phytas. Thus, it is obvious that musical literacy is studied from the small to the large, from a part to a whole, from the simple to the comple $x 5$.

On the other hand, the named process is necessarily accompanied by a constant deepening of the content aspect. This is a movement from the external form to the inner being of the notation chants, to their symbolic, theological, spiritual and moral depth; an infinite process of knowing God's world in such a way as it is embodied in sounds,

\section{[10]}


gaining the ability to testify about Truth. This is a reminder of the incess ant glorification of the angelic choir.

This complex process is accompanied by the knowledge of the person himself, his destiny, and sometimes spiritual struggle which is inevitable due to such a high mission. To a certain extent, the process of creation of the world and a man is also performed not within the church walls but in one's own soul.

This understanding influences the learning process. On the one hand, gradual ascent to an ideal adequate understanding of what is being performed is necessary, a process that could be carried out at the same stages, but in a different, reverse sequence from the definition of the simplest technical details (voice, genre, distribution of lines, hooks, etc.) to dogmatic and moral ideas and spiritual symbols.

On the other hand, the endless dialogue with the performed chant becomes one of the driving forces of moral perfection. Here, the main role is played by the leader of the choir. The educator who explains both the sacred words themselves and the meaning of them in a collapsed form draws analogies with the personal qualities and spiritual problems of the singers. This process only makes it possible to gradually feel the hymns and their appeal to a person as the Word of truth existing just for them and said to them. One cannot help but respond to the voice.

During training, singers are in a rather complicated pedagogical situation. It is extremely difficult, and, for some singers, it is even impossible to learn various chants and different versions of one song by heart otherwise known as "by melody". Therefore, one of the following options can be selected6.

Firstly, the master can only teach his own manner of chanting texts, a thing that represents a single singing tradition.

Secondly, the tradition adopted in a certain monastery is assimilated. It can assume the presence of several kinds of chanting, but each song has only a few basic singing variants fixed that can be learned in the foreseeable period of time.

Thirdly, the preparation for a specific service is conducted during which only one version of the chant is performed, and it is memorized just before the service.

In any case, the singers need huge mobility, an outstanding musical me mory and a great desire to sing in the choir so that such an intensive development of singing practice becomes possible.

Even more important is the following circumstance. Singing new chants of singing lines is impossible without fulfilling three basic conditions:

- written fixation of basic units of the chant and their systematization, which lead to the emergence of singing alphabet:

\footnotetext{
$6 \quad[11]$
}

- training of singers not only in the process of singing before the regular divine service, but also within the purposeful system of classes that is formed in the singing schools

- emergence of a didaskalos, a teacher whose main duty is to train young singers.

All these conditions are met in the 16th-17th centuries. A new, absolutely unique musical and educational environment is formed which determines not only the appearance of new types of liturgical singing but also the birth of the generation of new specialists who bring European educational traditions to Russia.

\section{CONCLUSION}

Analysis of the three-stage education in the ancient Russian singing art allows us to draw the following conclusions:

- Training takes place mainly in oral form under the guidance of an experienced pedagogue, i.e. a didaskalos. At the same time, a written didactic form of teaching has begun to play an increasingly important role since the 17 th century.

- The training books are structured as systematic manuals containing basic information on many main directions of church and singing culture: hook notation, the eight church modes, styles and chanting.

- In training, the principle of a sequential increase in complexity is used from the basic outline of the notation chants and its embodiment to the most sophisticated versions of hooks with a combination of postils.

- The principle of accessibility is used, i.e. transition to the next level happens only after complete assimilation of the previous one, as well as the principle of visibility is applied, i.e. the very insignia of the notation chants and the postils are vivid and expressive.

- When studying singing principles, gradual movement fro $m$ bright graphic inscriptions and figurative names to the most complex spiritual interpretations takes place.

- Books perform a mnemonic function serving as a guide for the sequential memorization of the material and, at the same time, contribute to its imprint in the mind.

- At the stage of primary education, the mastering of musical literacy is individual. In the future, there can be a collective singing of "sing studies", the alphabet is sung by an ensemble or by a choir (the tradition of post-reform training).

- The singing books become the keepers of the dogmatic and moral components of the singing culture; they teach not only the faithful singing of ecclesiastical tunes, but also morals, recall the virtues 
and spiritual foundations of the Christian dogma, imprint religious postulates in a vivid and imag inative manner.

\section{REFERENCES}

[1] N. Parfentiev, Professional Musicians of Russia of the XVI-XVII centuries. Chelyabinsk, 1991.P. 64.

[2] V. Zenkovsky, Principles of Orthodox Anthropology // The Russian Abroad in the Year of the Millennium of the Baptism of Russia, M., 1991, p. 7.

[3] History of Music Education: Ancient Russia: The end of X - the middle of the XVII century: Textbook for students of higher education institutions. M . Humanitarian publishing centre VLADOS, 2003.

[4] John of Damascus. An Exact Exposition of the Orthodox Faith M, Rostov-on-Don., 1992, p.134.

[5] E. V. Nikolaeva, pp. 134-135.

[6] Y. Keldysh, History of Russian Music: in 10 volumes, Vol. 1, M., 1983, pp. 65-89.

[7] S. Zvereva, Russian Choirs and Masters of Singing of the late XV mid XVII centuries (On the Problem of Singing Establishment in Medieval Russia), Author's abstract. ... art history PhD M., 1988, pp. 6-7.

[8] G. Wagner, Canon and Style in the Ancient Russian Art, M., 1987, p. 177.

[9] M.V. Brazhnikov, Old Russian Theory of Music. - L.: Muzyka, 1972, p. 36 .

[10] E. Polotskaya, Professional musical education in Ancient Rus: educational- methodical manual / Ural State Conservatory, M. P. Mussorgsky, 2002, p. 31.

[11] O.E. Sheludyakova, Problems of the Old Russian choir place education: tutorial. Urals Mussorgsky State Conservatoire, 2013, p. 216. 